\title{
Ekonomia Sozial eta Solidarioko esperientzien sustapena tokiko mailatik
}

\author{
Promotion of Social and Solidarity Economy from the local level \\ Pablo Arrillaga Márquez ${ }^{* 1}$, Aratz Soto GorrotXategi ${ }^{2}$, \\ Enekoitz ETXEZARreta ETXARri ${ }^{2}$ \\ ${ }^{1}$ GEZKI Institutua. Euskal Herriko Unibertsitatea (UPV/EHU) \\ ${ }^{2}$ Ekonomia Aplikatua Saila. Euskal Herriko Unibertsitatea (UPV/EHU)
}

\begin{abstract}
Laburpena: Urteetako esperientziak erakutsi duen bezala, tokian tokiko lurraldeetako garapen sozioekonomikoa erdieste aldera Ekonomia Sozial eta Solidarioa (ESS) akuilatzaile garrantzitsua izan daiteke. Zentzu honetan, tokiko garapena eta ESSren arteko harremanaz hausnartzen da lanaren hasieran. Baina ikusiko dugun bezala, paraleloki, tokiko erakundeek ESS sustatzeko duten politika publikoen kopuru eta aniztasuna handia da eta «bigarren belaunaldiko" gisa izendaturiko politikek ESSko esperientziak ernaltzeko aukera eskaintzen dute, tokiko garapen eta beharrei erantzun apropos bat ematen zaien bitartean. Artikulu honetan Euskal Autonomia Erkidegoan tokiko mailan diharduten eragileek hauspoturiko ESSko 16 esperientzien azterketa aurkezten da, bakoitzaren faktore bideratzaileak eta mugatzaileak arakatuz esperientziok beste lurraldeetan erreplikatu ahal izateko gakoak topatzeko asmoarekin.
\end{abstract}

Hitz gakoak: Ekonomia Sozial eta Solidarioa, Tokiko garapena, Politika publikoak, Garapen agentziak.

\begin{abstract}
As the experience has shown, the Social and Solidarity Economy can be an important incentive for the socio-economic development of local territories. In this sense, at the beginning of the work we reflect on the relationship between local development and ESS. But, as we will see, at the same time, the number and diversity of public policies of local entities for the promotion of ESS is enormous and the so-called "second generation" policies offer the possibility of fertilizing experiences of ESS, while providing a satisfactory response to local developments and needs. This article presents the analysis of 16 experiences of ESS promoted from the local level in the Autonomous Community of the Basque Country, exploring its facilitating and limiting factors, in order to find the keys to replicate them in other territories.
\end{abstract}

Keywords: Social and Solidarity Economy, Local development, Public politics, Development agencies.

Econlit gakoak: B55, $\mathrm{H} 70, \mathrm{R} 58$

* Harremanetan jartzeko/Corresponding author: Pablo Arrillaga Márquez. GEZKI Institutua. Euskal Herriko Unibertsitatea (UPV/EHU) - pablo.arrillaga@ehu.eus

Nola aipatu/How to cite: Arrillaga Márquez, Pablo; Soto Gorrotxategi, Aratz; Etxezarreta Etxarri, Enekoitz (2021). «Ekonomia Sozial eta Solidarioko esperientzien sustapena tokiko mailatik», GIZAEKOA - Revista Vasca de Economía Social, 18, 273-300. (https://doi.org/10.1387/gizaekoa.22921).

Jasoa: 2021/06/17; onartua: 2021/06/30.

ISSN 1698-7446 - elSSN 2444-3107 / (C) 2021 UPV/EHU 


\section{Sarrera}

Jarraian aurkezten dugun ikerketa lanak tokiko esparruan ekonomia sozial eta solidarioko (ESS aurrerantzean) esperientziak sustatzeko politika publikoetatik aurrera eraman litezkeen neurri konkretuen analisian sakontzea du xede.

Lan hau EGES ${ }^{1}$, Euskadiko Gizarte Ekonomiaren Sareak eginiko eskaera baten emaitza da, 2019 eta 2020 urteen artean buruturiko ikerketa egitasmo baten bitartez. Lan honetan, Euskal Autonomi Erkidegoan tokiko mailan (eskualde eta udal mailan), eta herri erakunde ezberdinen (udal edo garapen agentzia) parte hartzearekin aurrera eramandako praktika onen inguruko kasu azterketa bat egin da. Kasu horietan guztietan, ESSko esperientzia eta dinamika ezberdinak sustatzeko praktikak identifikatu dira, udalen ekimenez zein garapen agentzien egitekoen baitan garaturikoak, eta horien gaineko kategorizazio lan bat burutu da. Atal metodologikoan zehaztuko den gisan, kasu azterketen metodologia honek lehen mailako informazio iturrien ustiaketa eta kontraste fase ezberdinak izan ditu, aurkezturiko emaitzak behar besteko sendotasuna izatea bilatuz.

Guztira 16 esperientzia dira oinarrizko txostenean dokumentaturikoak eta landurikoak, eta horietan guztietan aztertu izan da esperientziaren oinarrizko deskribapen bat, ekimena aurrera eramatea erraztu eta zaildu duten faktoreen analisia, eta ekimenok lurralde osoan zehar barreiatzeko beharrezkoak liratekeen faktoreen gaineko analisia.

Lan honek, aldi berean, ESS sustatzeko politika publikoen ziklo berri baten testuinguruari erantzuten dio. Marko teorikoan justifikatuko den moduan, gai honetan adituak diren autore guztiek bat egiten dute oinarrizko abiapuntu batean: 2008an eztanda egin zuen krisi ekonomiko sakonak goitik behera astindu zuen ordura arteko egoera instituzionala oro har, eta baita politika publikoen joko taula ere, partikularki. Ordutik hona, «bigarren belaunaldiko" politika publikoez dihardugu, (Chavez, 2019; Chavez eta Gallego, 2020; Fajardo eta Chavez, 2019; Catalá, 2020), zeinetan bi ezaugarri nabarmentzen baitira lehen belaunaldiko politiken aldean: ESSren inguruko ezagutza eta aitortza maila zabalagoa, alde batetik; eta tokiko herri erakundeen protagonismo berritu bat, bestetik.

${ }^{1}$ Euskal Autonomia Erkidego mailako Gizarte Ekonomiaren ordezkaritza-erakundeen arteko lankidetza-esparru iraunkor moduan egituratzen da EGES, ondorengo erakundeen parte-hartzearekin: ASLE (Euskadiko Lan Sozietateen Taldea), EHLABE (Euskadiko Enpleguko Zentro Bereziak), GIZATEA (Gizarteratzeko eta Laneratzeko Euskadiko Enpresak), KONFEKOOP (Euskadiko Kooperatiben Konfederazioa) eta REAS Euskadi (Ekonomia Alternatibo eta Solidarioaren Sarea). 
Horrek guztiak azaltzen du azkenaldian gaiaren inguruan argitaratu diren lanen nolakotasuna ere. Geografikoki gertu, esan genezake Kataluniako eredua dela gaur gaurkoz aurreratuena, asko eta asko dira herrialde horretan eginiko politiken tipologizazioa (García, 2014; XES, 2018), deskribapena (García, 2016, XMESS, 2020), baita ebaluazioa ere (Chavez et al., 2019; García, 2019) egiten duten artikuluak. Antzeko ariketa egin izan dute komunitate Valentziarrean ere, kasu onen azterketez gain (Catalá, 2020; Chavez eta Savall, 2020) horren gaineko analisia (Fajardo eta Chavez, 2019) ere gehituz. Lan horiek guztiek espainiar estatu mailako analisi alderatuak egitea posible egin dute (Chavez, 2020) eta ildo beretik, bestelako argitalpen zabalago batzuk ere argitaratuak izan dira Europar Batasuneko mailan identifikaturiko politika publiko ezberdinen alderaketak jasoz (Chavez eta Monzón, 2019).

Inguruabar horretan kokatzen da jarraian aurkeztuko dugun ikerketa egitasmotik eratorritako emaitza nagusiak jasotzen dituen artikulu hau. Lana egituratzerako orduan, honakoa izan da jarraitu dugun argudio katea: lehen atal batean, lanaren sostengu teorikoa ezarri nahi izan da, hiru aspektu nagusitan oin hartuz: tokiko garapena eta ekonomia sozialaren arteko lotura, politika publikoen tipologia teorikoa eta bilakaera praktikoa, eta EAE mailan garaturiko politika nagusien berrikuspen kritikoa. Bigarren une batean lanaren azalpen metodologikoak xehatu dira eta honen atzetik, lorturiko emaitzen deskribapena eta analisia burutu da. Azkenik, lana ondorio orokorren atalak borobiltzen du.

\section{Tokiko garapena ESS bitartez sustatzeko politika publikoen inguruko hurbilpen teorikoa}

\subsection{Tokiko garapena eta ESS}

Labur esanda, tokiko garapenak, lurralde bateko bizi kalitatea hobetzeko helburuarekin, lurraldetik bertatik abiatzen diren garapen estrategia kolektiboak biltzen ditu (Pike et al., 2006). Ekonomia Sozial eta Solidarioak, bere aldetik, bazkideen eta komunitatearen beharrei erantzuteko sortutako izaera anitzeko erakunde kolektibo eta demokratikoak biltzen ditu. Hala ere, lan honen helburua ez da tokiko garapenaren edo ESSaren inguruko berrikuspen teorikorik egitea, baizik eta ESSko erakundeek tokiko garapenean izan dezaketen paperaren inguruko zertzelada batzuk ematea soilik.

Zentzu honetan, tokiko garapena eta ESSaren inguruko harremanak aztertu dituzten autore ezberdinen ekarpenak aipatu daitezke. Adibidez, Mozas eta Bernal-ek (2006) ESSak tokiko garapenari egin ahal dizkion hainbat ekarpen identifikatzen dituzte. Horien artean, ESSko erakundeak jarduten duten lurraldearekiko errotze handiagoa dutela azpimarratzen da. 
Izan ere, lurralde bateko ekintzaile talde batek, haien beharrak asetzeko, eta beraz, ongizatea hobetzeko asmoz, behar hauen gain eragiten duten elementuetan zuzenean jardun dezakete. ESSko erakundeak beraz, indar eta baliabide endogenoen mobilizazioaren bitartez sortzen dira, lurralde bakoitzean dauden pertsona taldeetatik sortutako enpresak baitira eta tokiko errealitateari lotuta daudelako.

Gainera, ESSko erakundeek duten jabego egiturarengatik, deslokalizaziorako eta itxiera selektiborako arriskua murrizten da, enpleguaren defentsa handiagoa emanez. Bestalde, demokratikoki kudeatzen diren erakundeak izaki, demokrazia ekonomikoan sakontzen dute, zeina tokiko garapenean positiboki eragiten duen faktore bat den, sortzen diren baliabide eta aberastasuna modu horizontalagoan banatzen baitute, besteak beste. Elementu hauez gain, autoreek, tokiko ekoizpen egitura sendoagoa garatzea ahalbidetzen duten beste elementu batzuk ere azpimarratzen dituzte: enpresen sareak sortzeko joera, garapen teknologikoa laguntzeko sortu ditzaketen egiturak edota etengabeko formakuntza prozesuak martxan jartzea, esaterako (Mozas eta Bernal, 2006).

Bestetik, Juste, Gómez eta Fernandez-ek (2011) lurraldeetako ongizateeta kohesio-soziala handitu dezaketen beste zenbait elementu antzematen dituzte ESSko erakundeetan. Izan ere, erakunde hauetan aberastasunaren banaketa bidezkoagoa ematen da, ohiko lan merkatutik baztertuta egon daitezkeen pertsonen enplegagarritasunean eragiten dute, gizartearen parte-hartzea sustatzen dute, garapen jasangarriago baten alde egiten dute eta enpresa kapitalistek muzin egiten dieten, baina baliagarritasun sozial handia izan dezaketen sektore edo jarduerak bere gain hartzen dituzte, besteak beste.

Guridi eta Pérez de Mendiguren-en arabera (2014), aurreko elementuez gain, ESSak pertsonen zein komunitatearen ahalduntzea helburu duen tokiko garapenaren ikuspegi batekin bat egingo luke. Izan ere, ingurunearen gaineko kontrola sustatzen laguntzen du, pertsonek jabetzan eta kudeaketan parte-hartzea ahalbidetzen duelako maila guztietan, bai enpresa-jardueretan, bai bizitza kultural, sozial, ekonomiko eta politikoko beste esparru batzuetan; ondorioz, lurralde burujabeagoak sortuz. Horrez gain, nortasun kolektiboa indartzen du lankidetzan, elkarrekiko konfiantzan eta konpromisoan oinarritutako kapital soziala garatzen laguntzen duelako.

Maila konkretuago batean, García Jané autoreak (2014) proposatzen duen analisi eskemari jarraiki, ESSko erakundeen artean tokiko garapenerako tresna edo funtzionaltasun ezberdinak betetzen dituzten erakundeak agertzen dira, bereziki honako esparruetan:

-Enplegua sortzeko tresnak: horien artean identifikatzen ditu ekintzaile kooperatibak, transformazio kooperatiboko prozesuak izan dituzten merkatal enpresak, hezkuntza kooperatibak, etab. 
-Finantzaketa tresnak: horien artean finantza etikoei loturiko banka edo bestelako finantza zerbitzuak (Fiare, Koop 57, Oikokredit...), kooperatibetan bazkide kolaboratzaile gisa diharduten herri erakundeak, titulu parte hartzaileak, elkarrekiko berme sozietateak, mikrofinantza egitasmoak, aurrezki solidarioko taldeak, etab.

_Eskaria sustatzeko tresnak: 2017ko Sektore Publikoko Kontratuen Legeak $^{2}$ sorturiko baldintza berrien testuinguruan herri erakundeen kontratazio prozesuetan gizarte klausula edo merkatu erreserben bitartez balio konkretu batzuen arabera diharduten enpresak positiboki diskriminatzeko, baina baita bestelako dinamika posible batzuk ere: cashmob dinamikak, tokiko moneten esperientziak, etab.

—Eskaintza hobetzeko tresnak: tokiko zerbitzuak kooperatiben bitartez eskaintzeko esperientziak, etiketa eko-sozialak, gertutasunezko ekonomiak, etab.

-Ondasun publikoak sortzeko tresnak: ahanzturiko espazioen berreskurapen publikorako dinamikak, negozio pribatuen birmoldaketa publikoa, etab.

-Ondasun publikoak birbanatzeko tresnak: aurrekontu parte hartzaileen esperientziak kasu.

- Aurrezki indibidual eta kolektiborako tresnak: denboraren bankuak edo kontsumo kolaboratiboaren logiketan diharduten egitasmoak.

Autore honen argudio lerroarekin jarraituz, Ekonomia Sozial eta Solidarioko erakundeak tokiko garapenerako "tresna kutxa» gisa hauteman litezke, lurraldeak behar dituen mota ezberdinetako baliabideak aktibatzeko (ekintzailetza, finantzazioa, eskaria, eskaintza, ondasun publikoen atzidura, etab) erakunde egokiak izan bide direlakoan.

Gure analisi eskeman ere modu bertsuan lerrokatuko ditugu ESS sustatzeko esku hartze ereduak, helburuak, eta antolakuntza mota egokienak, jarraian garatzen dugun taulan jasotzen ditugun moduan:

Lehen sarrera honen bitartez, beraz, agerian geratzen den lehen ideia honako hauxe litzateke: ESS osatzen duten erakundeek, antolakuntza modu eta gizarte funtzio ezberdinei erantzuten dieten enpresa anitzak izanik, tokiko garapenak ager ditzakeen behar ezberdinei erantzuteko baliabide ezberdinen aktibazioan modu doituan erantzun dezaketen «tresna kutxa» anitza osatzen dutela.

${ }^{2}$ https://www.boe.es/buscar/act.php?id=BOE-A-2017-12902 


\section{1. taula}

Ekonomia Sozial eta Solidarioko antolakundeak esku hartze publikoaren helburuen arabera

\begin{tabular}{l|l}
\hline \multicolumn{1}{c|}{ Esku hartzearen helburu nagusia } & \multicolumn{1}{c}{ Antolakuntza mota egokiena } \\
\hline $\begin{array}{l}\text { 1. Elkartegintza eta parte hartze } \\
\text { herritarra bultzatzea }\end{array}$ & $\begin{array}{l}\text { Erabiltzaile elkarteak. } \\
\text { Erabiltzaile kooperatibak. }\end{array}$ \\
\hline $\begin{array}{l}\text { 2. Jarduera ekonomikoaren kolek- } \\
\text { tibizazioa }\end{array}$ & $\begin{array}{l}\text { Jarduera ekonomikodun elkarteak. } \\
\text { Lan elkarteak. } \\
\text { Lan elkartuko kooperatibak. }\end{array}$ \\
\hline $\begin{array}{l}\text { 3. Jarduera ekonomikoaren bi- } \\
\text { dezko gizarte integrazioa }\end{array}$ & $\begin{array}{l}\text { Gizarte ekimeneko kooperatibak. } \\
\text { Laneratze enpresak. }\end{array}$ \\
\hline $\begin{array}{l}\text { Enplegu zentro bereziak. } \\
\text { tibo - komunitarioko formulak }\end{array}$ & $\begin{array}{l}\text { Parte hartze publikodun kooperatiba integralak. } \\
\text { Fundazio publikoak. }\end{array}$ \\
\hline
\end{tabular}

Iturria. Geuk egina.

\subsection{ESS sustatzeko politika publikoak: tipologia eta azken urteetako bilakaera}

Horiek izanik ESSko erakundeen bitartez tokiko garapenari loturik erdietsi litezkeen helburu nagusiak, gatozen orain herri erakundeen aldetik ESSko erakundeen sustapenerako baliatu litezkeen esku hartze ereduen analisira. Bitan banatuko dugu atal hau: maila teorikotik bereizten diren tipologiak azalduko ditugu lehen lehenik, eta ondoren, horiek espainiar estatu mailan azken 10 urteetan izan duten bilakaeraren errepaso labur bat eskainiko da, hirugarren ataleko esperientzia praktikoen testuinguru teoriko-praktikoa ezartze aldera.

\subsubsection{Politika Publikoen tipologia nagusiak}

Politika publikoen tipologien kategorizazioa egiteko Rafael Chaves ikerlariak IUDESCOP ikerketa taldearen baitan egin izan dituen lan aurrekariak $(2009,2010,2012)$ eta horien garapenak izango ditugu euskarri nagusi. Funtsean, autore horiek ESS erakundeak sustatzeko bi bide nagusi zehazten dituzte, lehen lehenik: ESSko erakundeei zuzenean eragiten dieten neurriak hartuz, edo bigarren maila batean, enpleguari bideraturiko neurrietan eraginez, zeinak zeharka eragin bailezake ESS erakundeen en- 
plegu sorreran edo mantentze neurrietan. ESSari zuzenki bideraturiko neurrien barruan ere, bi ikuspegi osagarritzen dira: eskaintzari eragiten diotenak (erakundeen egituretara bideratuak) edo eskariari eragiten diotenak, ESSari eragiten dioten merkatuak zabalduz.

Jarraian aurkezten dugun taulan zehazten ditugu tipologia nagusiak:

\section{2. taula}

Ekonomia soziala sustatzeko politika publikoen tipologia nagusiak

\begin{tabular}{|c|c|c|}
\hline \multicolumn{3}{|c|}{ Ekonomia sozialeko erakundeei bideraturiko politikak } \\
\hline \multicolumn{3}{|c|}{ ESKAINTZAREN ALDEKO POLITIKAK (erakundeen egituretara bideratuak) } \\
\hline $\begin{array}{c}\text { Neurri } \\
\text { Instituzionalak }\end{array}$ & $\begin{array}{l}\text {-Ekonomia sozialaren aitortza eragile pribatu gisa. } \\
\text { —Ekonomia sozialaren gaitasun operatiboaren ai- } \\
\text { tortza edozein jarduera ekonomikotan. } \\
\text { —Ekonomia sozialaren aitortza eragile politiko gisa. } \\
\text {-Ekonomia sozialaren sustapeneko erakunde pu- } \\
\text { blikoak. }\end{array}$ & $\begin{array}{l}\text { Soft politikak edo } \\
\text { politika leunak }\end{array}$ \\
\hline $\begin{array}{c}\text { Neurri } \\
\text { kognitiboak }\end{array}$ & $\begin{array}{l}\text { —Ekonomia sozialaren hedapen, formazio eta iker- } \\
\text { keta. }\end{array}$ & Politika leunak \\
\hline $\begin{array}{c}\text { Neurri } \\
\text { ekonomikoak }\end{array}$ & $\begin{array}{l}\text {-Aurrekontu publikoak. } \\
\text { —Zerga politikak. } \\
\text { —Laguntza finantzariko bestelako neurriak. } \\
\text { —Laguntza teknikoko neurriak. }\end{array}$ & $\begin{array}{l}\text { Hard politikak edo } \\
\text { politika sendoak }\end{array}$ \\
\hline \multicolumn{3}{|c|}{ ESKARIAREN ALDEKO POLITIKAK (erakundeen jarduerara bideratuak) } \\
\hline \multicolumn{2}{|c|}{$\begin{array}{l}\text { —Herri erakundeen hornitzaile izatea ahalbidetzeko neurriak. } \\
\text { —Ekonomia sozialarekin elkargo publiko-pribatuak ezartzeko apli- } \\
\text { kazio eta erregulazio neurriak. }\end{array}$} & Politika sendoak \\
\hline \multicolumn{3}{|c|}{ Ekonomia sozialeko erakundeetako enpleguari bideraturiko politikak } \\
\hline \multicolumn{2}{|c|}{$\begin{array}{l}\text {-Ekonomia sozialean enplegua sortu eta egonkortzeko laguntza } \\
\text { neurriak. } \\
\text { —Ekonomia sozialean prestakuntza laguntzeko neurriak. } \\
\text { — Bestelako neurriak. }\end{array}$} & Politika sendoak \\
\hline
\end{tabular}

Iturria. Geuk egina Chaves (2012) oinarri hartuz.

Laburbilduz, funtsean bi dira hasierako hurbilketak: Ekonomia Sozial eta Solidarioko erakundeengan zuzenki edo horien enpleguan zeharka eragiten duten enplegu politika orokorragoen bitartez ekin lekioke sustapen 
lan horri. Horretaz gain, izaera gogor edo leunagoko neurriak har litezke. Izaera leuneko neurriak, ESSren garapenerako baldintza egokiak sortzea dute xede, dela neurri instituzionalen bidez (ESS eragile instituzional gisa aitortuz herri-erakundeen esparru edo dinamika ezberdinetan), dela neurri kognitiboen bitartez (ESSko esperientziak ikertu, bistarazi eta jendarteratuz). Neurri sendoen artean, berriz, ESS erakundeetan eragin zuzena duten neurriak leudeke, horien egiturak sendotuz (mota ezberdinetako neurri ekonomikoen bitartez, diru-laguntza publiko, hitzarmen edo ituntze neurriak, zerga hobariak eta abar) edo horien eskaria bizkortuz, nagusiki herri erakundeek egiten duten eskari publikoa ESSko erakundeek egiten duten eskaintza ekonomikoarekin bateratuz.

\subsubsection{LEHEN BELAUNALDITIK BIGARRENERA: ESPAINIAR ESTATU MAILAKO POLITIKA PUBLIKOEN AZKEN URTEETAKO BILAKAERA}

Artikuluaren sarreran aurreratu dugun gisan, azken lau hamarkadatan abian jarri diren neurriei erreparatuz gero, inflexio puntu bat antzematen da espainiar estatu mailan 2008ko krisiaz geroztik. Data horretara arte gailenduriko sustapen politikek, «lehen belaunaldikotzat» jo genitzaken horiek, ESSaren ikuspegi murrizkor batean oinarritzen ziren lehenik, soilik kooperatiba eta lan elkarteak hartzen baitziren aintzat sustatu beharreko erakundeen artean; eta bigarrenik, herri-erakundeen eskala anitzeko banaketari dagokionez, administrazio zentralak zein autonomia erkidegoek hartzen zuten lidergoa, eskualde zein tokiko mailako erakundeen parte hartze eskasarekin (Chaves, 2019).

Ordutik hona, aldaketa sozioekonomiko eta politiko sakonekoak gertatu dira eta, esan bezala, 2008an leherturiko atzeraldiak ageri agerian utzi zituen esku hartze eredu horien ahulgune nabarmenenak: horien eragin mugatua ESSko erakundeen hedapen errealean. Bereziki ekintzailetza berrien aktibazioan eta orokorrean, tokiko garapenarekin agertzen zuten erabateko deskonexioan.

Gogoeta hori, kasik modu sinkronizatuan gurutzatuko da tokiko garapen politiken berrikuspen orokor batekin, esparru horretan diharduten aditu ezberdinen iritzian (Subirats, 2014; Estela, 2014...) 2008ko krisiak ere agerian utziko baitu tokiko garapenerako aktibaturiko esku hartze ereduen akidura edo agortzea.

Bi gogoeta horien gurutzaketatik sortzen dira, hain zuzen ere, «bigarren belaunaldikoak» deituriko politika publiko berriak. Fajardok (2019) hiru mugarri seinalatzen ditu trantsizio honetan: i) 2011 ko espainiar estatuko Ekonomia Sozialeko 5/2011 legeak ekonomia sozialaren unibertsoa legez definitua utziko du; ii) Ekonomia Sozialeko Espainiar Estrategiaren (2017-2020) baitan tokiko esparruak harturiko garrantzia, eta; iii) Azken urteetan, nagusiki 2015ko udal hauteskundeek utziriko botere korrela- 
zio berrien baitan, udal garrantzitsuetan garaturiko estrategia berritzaileak: Madrilen, Bartzelonan, Zaragozan, Sevillan, eta abar.

Horien analisi xehatuan sartu gabe, autoreak bi berrikuntza nagusi hautematen ditu garapen normatibo berriotan: ekonomia sozialaren kontzeptuaren zehaztapen handiagoa, alde batetik; eta tokiko zein eskualde mailako esparruen protagonismo berritua, bestalde (Fajardo, 2019).

Chaves-ek (2019) lau ezaugarri nagusiren bitartez zedarritua utziko du «bigarren belaunaldiko» politiken nolakotasuna:

- Bottom-up logikari eusten dioten politikak dira, top-down ikuspegia ordezkatuz. Ekonomia Sozial eta Solidarioak, beraz, parte hartze esanguratsua izango du politika berri horien diseinu, planifikazio eta inplementazioan, herri erakundeek gidaturiko programetatik ko-eratze eskemetara igaroz.

-Ikuspegi holistikoa lehenesten duten politikak dira, laguntza ekonomikoan oinarrituriko neurri isolatuak ordezkatuz.

- Ikuspegi ekosistemikoan oinarritzen dira, aurrekontuan oinarrituriko ikuspegiak gaindituz. Modu honetan, lurraldeko eragile ezberdinek aktiba ditzaketen baliabideak dinamizatzea da xede nagusia, horien parte hartzea modu egituratuan ahalbidetzeko plataformen bitartez.

- Mainstream ikuspegi batetik hartu nahi diren neurriak dira, neurrion zeharkakotasuna eta osagarritasuna bilatuz tokiko politika publiko ezberdinen artean, udal sail bakoitzak modu isolatu eta deskoordinatuan harturiko neurrien esku hartze ereduak gaindituz.

Funtsean, bigarren belaunaldiko neurri horiek, aurrekontu partida esanguratsuagoak izan eta eskala lokalagoan eragiteaz gain, politika publikoetan egindako gizarte berrikuntzetan oinarritzen dira. Berrikuntza horien bitartez, ESSko erakundeetan ez ezik, lurraldeko bestelako erakundeetan eragingo duten neurriak hobesten dira, lurraldean eragitea baita helburu nagusia, teorian honen beharrizanak erdigunean jarrita.

\subsection{EAEko ESSren sustapenerako politika publikoak: berrikuspen labur bat}

Gauza jakina da Euskal Autonomia Erkidego (EAE) mailan Gizarte Ekonomiaren Zuzendaritzak gidatu izan duela nagusiki ekonomia sozialaren sustapenerako politika publikoen alorra. Politika publiko horiek mota sendoko zein leuneko neurriak kontenplatzen dituzte, aurretiaz egindako hainbat lanetan jasoa geratzen den moduan (Bakaikoa eta Morandeira, 2012; Morandeira, 2013).

Nolabait laburbiltzearren orain arte indarrean izan den sustapen ildoa, beste artikulu batean modu xehatuagoan garaturiko ideia nagusiak ekarriko ditugu lerrootara (Morandeira, Etxezarreta eta Etxebarria, 2020): 
- Politika leunen aldean, instituzionalki garapen garrantzitsua izan du ekonomia sozialak EAE mailan. Gizarte Ekonomiako Zuzendaritza bera litzateke honen adibide nagusia, baina baita bestelako erakunde publiko-pribatuen existentzia zabala ere, nagusienak aipatzearren: Euskadiko Kooperatiben Goren Kontseilua, Erkide, Elkarlan, Bitartu, GEZKI institutua (UPV/EHU), OVES-GEEB behatokia (UPV/EHU), EGES sarea, etab.

-Erakunde horiez gain, EAEk eskuduntza osoa du kooperatibak, elkarteak, fundazioak, borondatezko gizarte aurreikuspen erakundeak eta arrantzale kofradiak arautzeko.

- Bestalde, ekonomia sozialak badu presentzia erkidego mailako bestelako kontsulta organoetan ere, besteak beste, Euskadiko Ekonomia eta Gizarte Arazoetarako Batzordean, ez ordea Lanbiden, sektoreak aspaldidanik aldarrikatu izan duen arren, sistematikoki ukatu izan zaiolako.

- Hezurdura instituzional sendo honetaz gain, EAEri Itun Ekonomikoak damaion zergen gaineko eskumen erregulatzaileak posible egiten du kooperatibek, elkarteek zein fundazioek zerga politika bereiztua izatea, nagusiki kooperatiben mozkinen gaineko zergan tipo murriztuak ezartzen dituena, horien zerga oinarriaren kalkuluan bestelako hobariak ere barneratzen dituelarik.

- Neurri kognitiboen atalean, EAEko unibertsitate sistemako unibertsitate publiko zein pribatu guztietan dauden institutu zein ikerketa talde espezializatuen existentzia nabarmendu behar litzateke ${ }^{3}$. Neurri horiez gain, ekonomia sozialeko erakundeentzako soilik bideraturiko diru laguntzen partida bertsuak mantendu izan dira tradizional$\mathrm{ki}^{4}$ (Bakaikoa eta Morandeira, 2012).

Laguntza ildo horiek egokitzen eta doitzen joan dira sektorearen beharrizan aldakorretara, eta oro har, partida nagusi horiek mantendu izan diren arren denboran zehar, horietako batzuk desagertu ere egin dira azken deialdietan (inbertsiotarako, ikerketa bekak). Ildo bakoitzak Zuzendaritzak kudeatzen duen guztizko partidan duten pisu erlatiboari erreparatuko bagenio, argi ondorioztatzen da ekintzailetasuna sustatzeko partidara bide-

3 GEZKI eta OVES-GEEB UPV/EHUn, Lanki eta MIK Mondragon Unibertsitatean eta Zuzenbide Kooperatiboko Institutua, Deustuko Unibertsitatean.

${ }^{4}$ Gizarte Ekonomian ekiteko laguntzak; Gizarte Ekonomiako enpresen elkarte egiturak sendotzeari zuzendutako laguntzak.Gizarte Ekonomiaren arloan ikasketak zabaltzeko beka. Gizarte Ekonomiako enpresetan laguntza teknikorako diru laguntzak. Gizarte Ekonomiaren prestakuntzarako laguntzak.Gizarte Ekonomiako enpresa-lankidetzarako laguntzak. Enpresetan langileen parte-hartzea bultzatzeko laguntzak. Gizarte Ekonomiako enpresetan bazkideak barneratzeko laguntzak. Inbertsioak burutzeko laguntzak. Aldi baterako langabezia jasaten duten bazkide langileen edo lan-bazkideen kualifikaziorako laguntzak. 
ratzen dela esfortzurik handiena (aurrekontuaren \% 40, 2019an), honen atzetik kokatzen direlarik prestakuntzara bideratuak (\% 16) eta enpresen elkarte egiturak sendotzeko partidak (\% 15,5) (Morandeira et al., 2020).

Argazki orokorra osatze aldera, ekonomia sozialeko erakundeen eskarian zein enpleguan eragiten duten neurriak ere barneratu behar lirateke gure analisian. Laguntza horiek, alabaina, Gizarte Ekonomiaren Zuzendaritzaren eragite esparrua gainditzen dute, zuzendaritza hau Lan eta Justizia sailean kokatua den neurrian, kooperatiba eta lan elkarteei soilik eragiteko gai baita.

Jarraian eransten dugun irudian jasoa geratzen da Ekonomia Sozial eta Solidarioko erakunde guztien interlokuzio eremua EAEko herri-erakundeen aurrean:

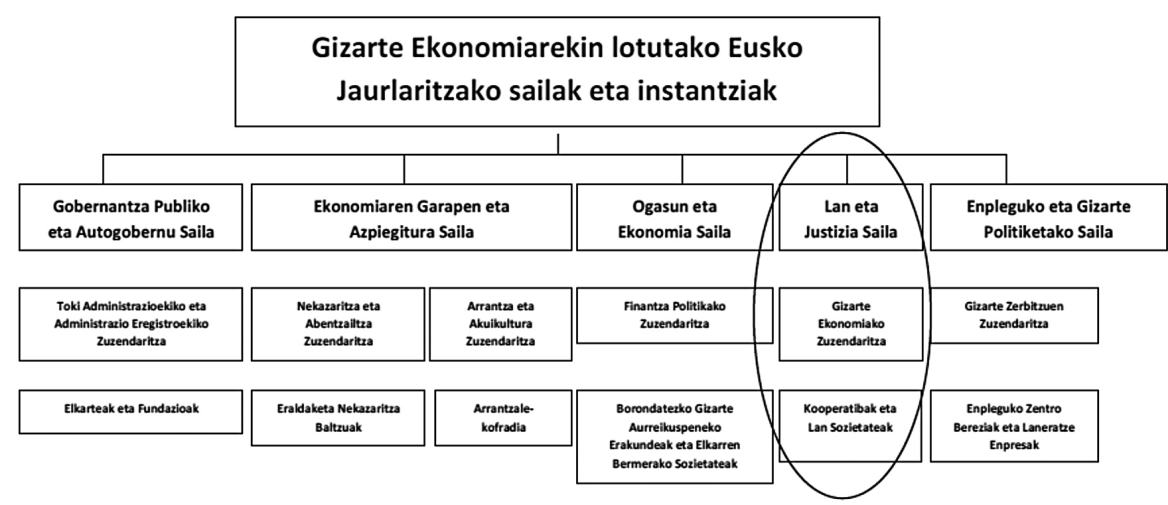

Iturria. Gizarte Ekonomiako Zuzendaritzaren Jarduketa Plana (2017-2020).

\section{1. irudia}

Ekonomia Sozial eta Solidarioko erakundeen kokapen instituzionala

Irudian jasoa geratzen den bezala, ESSko erakunde nagusiak, hots kooperatibak eta lan elkarteak, Lan eta Justizia sailean kokatzen diren arren, horien jarduera eremuagatik ere bestelako sailetan txertatuak egongo dira (dela hezkuntza, dela industria, dela gizarte zerbitzuak. etab). Bestalde, unibertso honetako beste erakunde motek ere interlokuzio zuzena dute beste sail batzuekin: Enplegu eta Gizarte Politiketako sailarekin laneratze enpresa eta enplegu zentro berezien kasuan, Gobernantza Publiko eta $\mathrm{Au}-$ togobernu saila elkarte eta fundazioen kasuan, etab.

Errealitate instituzional konplexu honek ekartzen du ekonomia sozialeko erakundeak sustatzeko neurriak alde anitzetatik eratorri ahal izatea, analisian konplexutasun handia erantsiz horien identifikazio eta esangura neurtze aldera. Zentzu berean, zailtasunak ere ezartzen ditu sektorearen 
gaineko estrategia orokor bat ezartzerakoan, sail ezberdinen parte hartze koordinatua eskatzen duen heinean. Amai dezagun lehen atal hau Gizarte Ekonomiako Zuzendaritzak 2017-2020 urtealdirako ezarritako Jarduketa Planaren inguruko ohar labur batzuekin.

Plan honen diseinu eta elaborazio prozesuan, baita bere sakoneko ikuspegian ere, «bigarren belaunaldikotzat» jo ditugun orientabide batzuk hauteman litezkeela ondorioztatzen da, ekonomia sozialeko eragileen parte hartze zuzena eta aktiboa bilatu baita (bottom-up ikuspegia) eta nolabaiteko zeharkakotasuna ere erdietsi nahi izan baita (ikuspegi holistikoa eta mainstream). Horrez gain, laguntza ildoen helburu estrategikoen artean, berrikuntza nagusia ekintzailetza sustatzeak hartu duen berebiziko lehentasunean datza.

Ekintzailetza sustatzeko lerroan sakontzeak bat egiten du, bete betean, jarraian aurkezten dugun ikerketa egitasmoaren izpiritu eta asmoarekin. Xehatu ditzagun hortaz lorturiko emaitza nagusiak.

\section{ESSa sustatzeko praktika egokien inguruko azterketa}

\subsection{Azterketaren inguruko ohar metodologikoak}

Garapen agentzietatik ESSa sustatzeko praktika egokien inguruko analisirako 16 esperientzia aztertu dira. Hasierako mapeoa egiteko, esperientziak zehaztu ziren tokiko garapeneko eragileen, ESSaren erreferentziazko eragileen eta ikerketa burutu dugun ikertzaileon artean. Hala, lan honetan aurkezten ditugun kasuen behin betiko zerrendan, eragileek eurek zehaztutako esperientzia esanguratsuenak jaso dira.

Behin aztertu beharreko esperientziak zehaztuta, elkarrizketa bana burutu zen kasu bakoitzeko erreferentziazko pertsonekin. Elkarrizketa hauen bitartez, esperientzia bakoitzaren jardueraren deskribapena, faktore bideratzaile eta mugatzaileak eta jarduera erreplikatzeko beharrezkoak diren baldintzak aztertu nahi izan dira bereziki.

Ondoren, jasotako informazioarekin burututako dokumentazioaren kontrasteak bi fase izan ditu. Lehenengo fase batean, esperientzien oinarrizko informazioa eman duten pertsonen berariazko baliozkotzea jaso da. Eta bigarren fase batean, azterketaren emaitza orokorrak talde-dinamika baten bitartez ere aurkeztu eta bateratu dira. Focus Group izaera hartu duen dinamika honetan, aurretiaz elkarrizketatutako pertsonak elkartu ziren bi helburu nagusirekin: behin behineko emaitza orokorrak aurkeztea eta esperientziak beste tokietan erreplikatzeko beharrezkoak diren elementuak elkarren artean identifikatzea.

Hurrengo taulan aztertutako esperientzien ezaugarri nagusienak agertzen dira modu sintetikoan: 
EKONOMIA SOZIAL ETA SOLIDARIOKO ESPERIENTZIEN SUSTAPENA TOKIKO MAILATIK

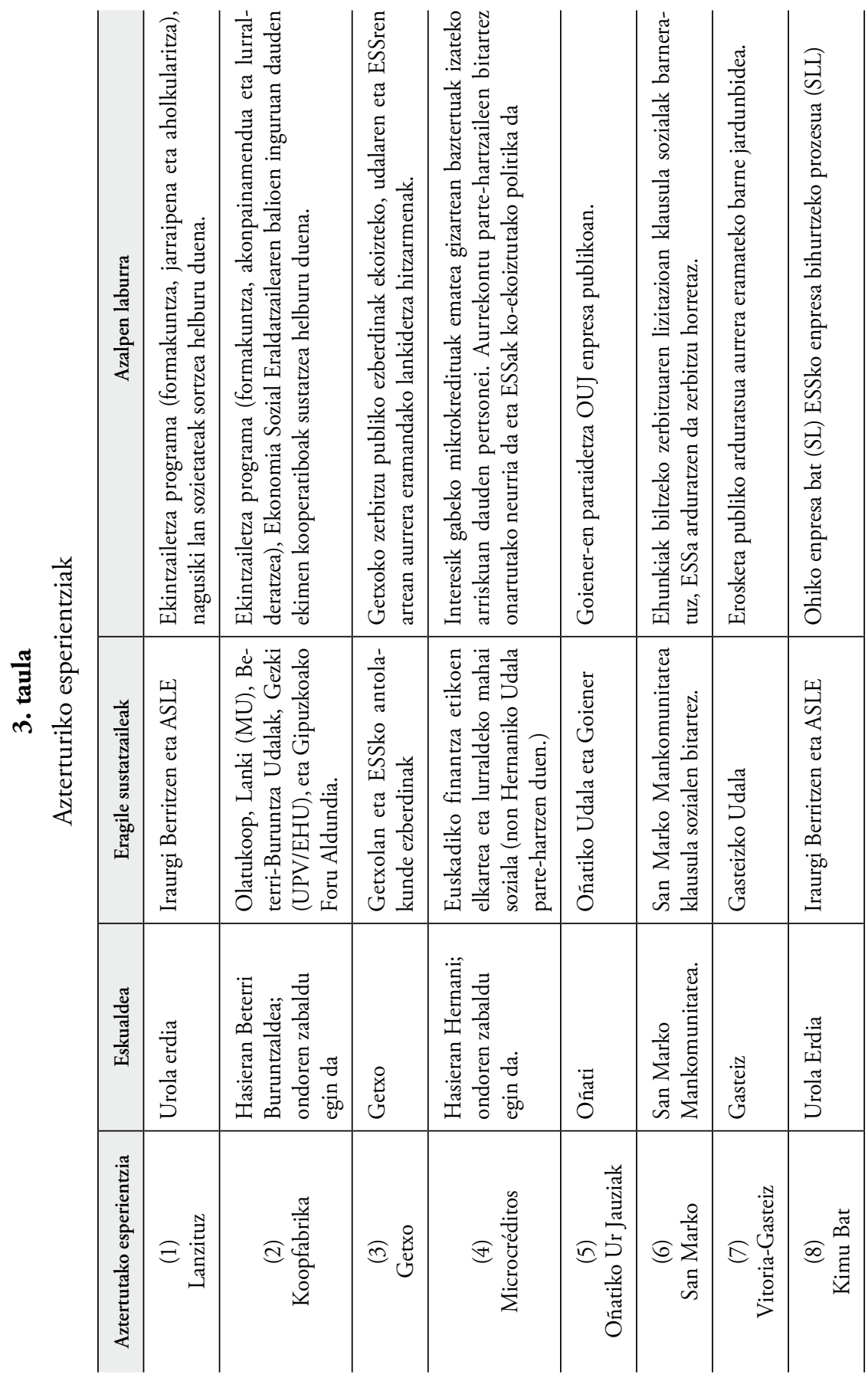




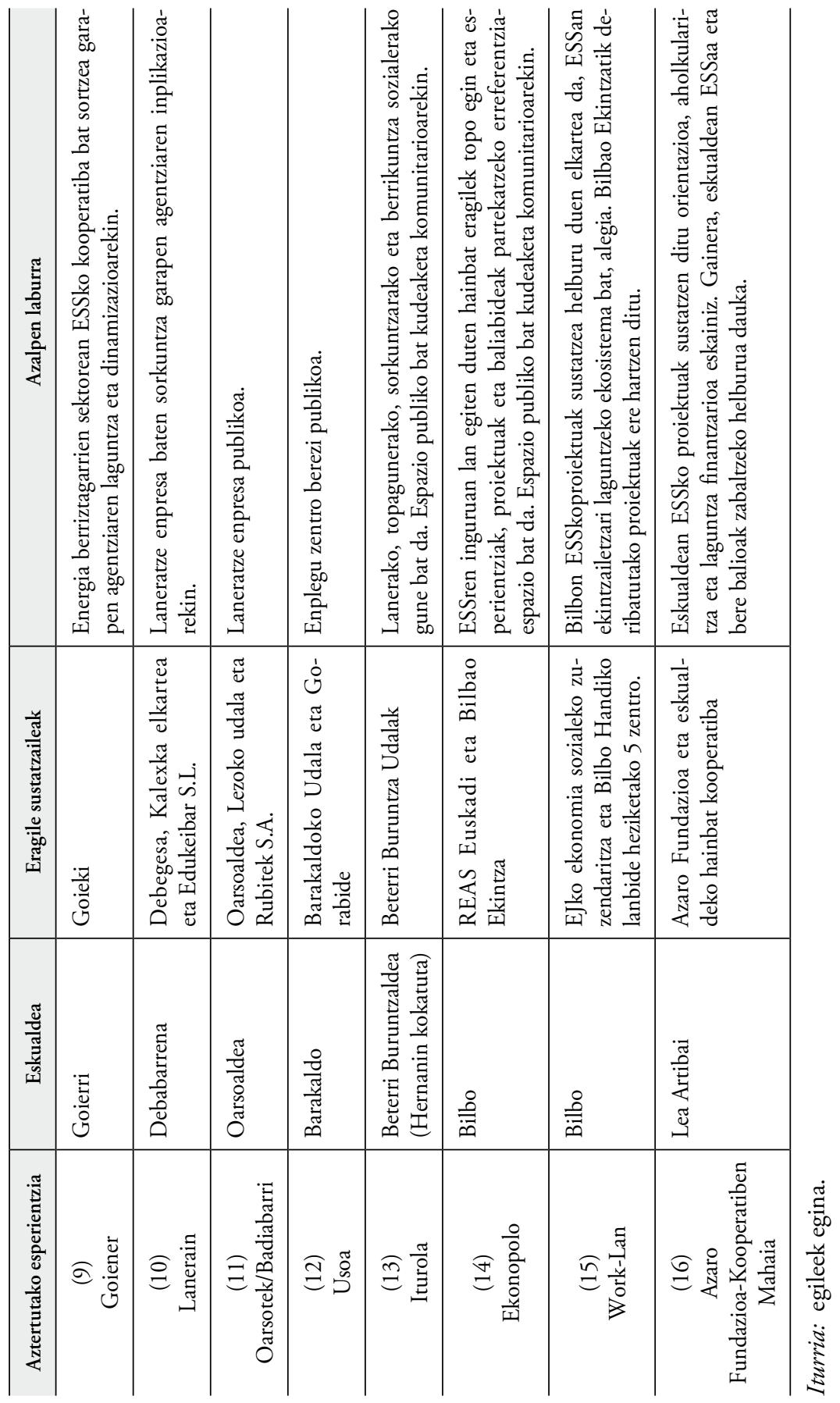




\subsection{Esperientzien sailkapena ESSa sustatzeko politika publikoen marko orokorraren arabera}

ESSa sustatzeko politika publikoen marko orokorra aztertu ondoren, bi jarduera-ildo nagusi daudela ondorioztatzen da: alde batetik, zuzenean ESSko antolakundeei eragiten dieten politikak, eta bestetik, ikuspegi orokorrago batetik abiatzen direnak —enplegua sustatzea-, baina, era berean, zeharka eragiten dizkiotenak ESSko erakundeetako enplegu partikularrari.

Aztertutako 16 esperientziei dagokienez, gehienak bigarren ildotik doaz, ekintzailetza programa edo egitura ezberdinekin lotuta baitaude (1., 2., 8., 9., 10., 11., 12., 13., 14., 15. eta 16. esperientziak). Izan ere, tokiko garapen agentzien eskumenak, neurri handi batean, tokiko enplegu-politiketan zentratzen dira. Hala ere, enplegua sustatzea helburua duten politika hauek ESSko antolakundeen gain nola eragiten dutenaren arabera, neurrien bloke ezberdinak ere sailka ditzakegu.

Oro har, enpresen sorkuntzan, ekintzailetza sustatzeko egituren sorkuntzan eta formakuntza oinarri duten eskaintzako neurri kognitiboetan oinarritzen dira. Gainerako kasuek zerikusi handiagoa dute kontratu publikoen, zerbitzu publikoen edo azpiegituren lagapenaren bidezko azpi-kontratazio prozesuekin edo ekonomia solidarioko esperientziak sustatzearekin (3., 4., 5., 6. eta 7. esperientziak).

Aztertutako esperientziak ESSaren sustapenerako politika publikoen marko orokorrean kokatzearren, hurrengo taulan biltzen den sailkapena proposatzen dugu 5 .

Taulan ikus dezakegun moduan, arakaturiko esperientziak bi multzo handietan banatu dira. Batetik, ESSko antolakundeei zuzendutakoak, eta bestetik, ESSko enpleguari bideratutakoak.

5 Sailkapena modu propositiboan egiten da, esperientzia bakoitzaren ezaugarri nagusien araberako kokapenaren arabera. Izan ere, sailkapen ariketa oro berrikusi eta berrantolatu ahal izango litzateke, aztertutako esperientzia guztiak polifazetikoak baitira, eta, beraz, kasu askotan ESSa sustatzeko tresna bat baino gehiago hartzen baitute. Proposatzen dugun sailkapenak, azken batean, esperientzia bakoitza sustapen tresna batean edo bestean zehatz-mehatz kokatzea baino,garapen agentziek edo/eta tokiko erakundeek jarduteko dituzten aukerak argiago identifikatzea du helburu. 
PABLO ARRILLAGA MÁRQUEZ, ARATZ SOTO GORROTXATEGI, ENEKOITZ ETXEZARRETA ETXARRI

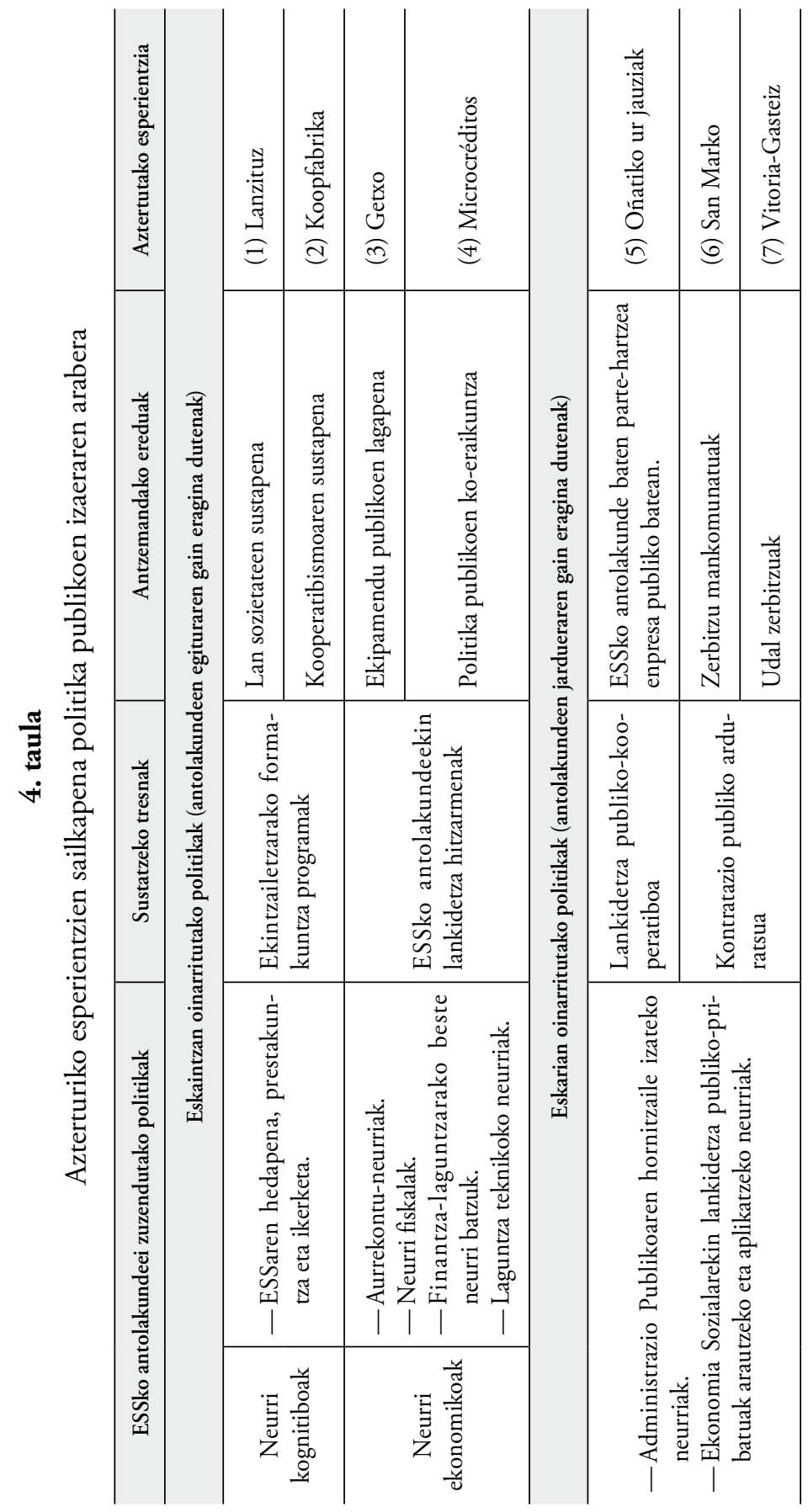


EKONOMIA SOZIAL ETA SOLIDARIOKO ESPERIENTZIEN SUSTAPENA TOKIKO MAILATIK

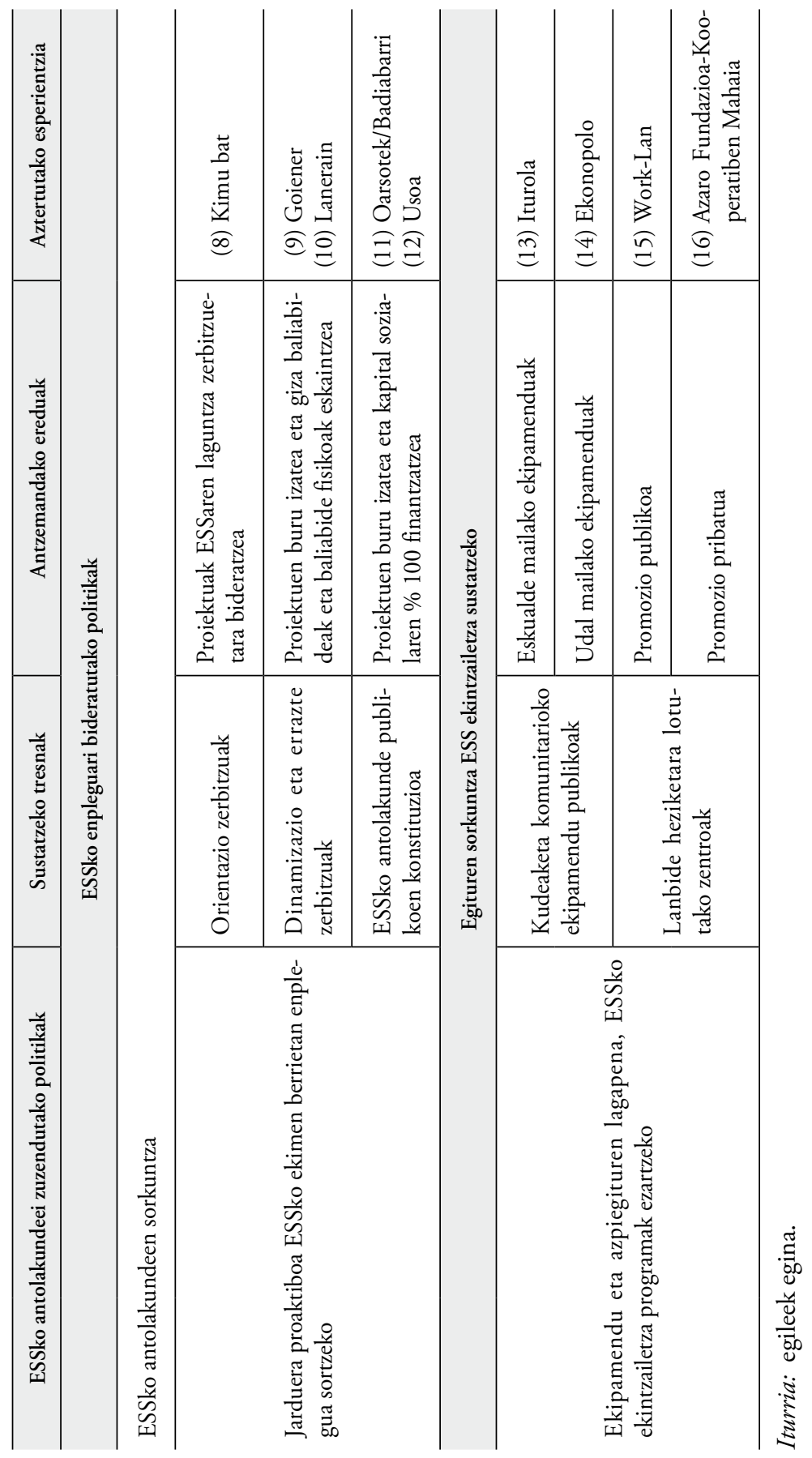


Lehenengoen artean, eskaintzan eta eskarian oinarritutako neurriak bereizi dira. Hots, antolakundeen egituraren gain eragiten dutenak batetik, eta antolakundeen jardueraren gain eragiten dutenak bestetik. Eta aldi berean, eskaintzan oinarritutako neurriak bi izaera ezberdin izan ditzakete: kognitiboak eta ekonomikoak. Neurri kognitiboak ESSa hedatzeko eta ESSan prestatzeko eta ikertzeko neurriak lirateke. Bertan, ESSko ekintzailetzarako bi prestakuntza-programa kokatzen dira: Lanzituz (lan-sozietateak sustatzeko programa) eta Koopfabrika (Ekonomia Sozial Eraldatzailearen paradigman kooperatibagintza sustatzeko programa). Izaera ekonomikoa duten neurrietan aldiz, Eusko Jaurlaritzak bideratu ohi dituen diru-laguntza ildoetatik haratago, tokiko administrazio publikoaren eta ESSaren arteko lankidetza hitzarmenak jaso dira. Izan ere, tresna hau, mota askotako jarduerak biltzeko lanabes juridiko izan daiteke. Horren isla dira, adibidez, Getxoko hainbat udal zerbitzuren ko-kudeaketa esperientziak edo Gipuzkoako hainbat udaletan garatu diren mikrokredituen bidezko gizarte politiken ko-eraikuntza hitzarmenak.

Eskarian oinarritutako neurriek administrazio publikoaren eskaria ESSko antolakundeek eskaintzen duten ondasun eta zerbitzuetara egokitzea bilatzen dute. Ildo honetan, bi neurri ezberdin antzeman ditugu aztertutako esperientzien artean. Alde batetik, erosketa publiko arduratsua, non Gasteizko Udaleko eta San Marko mankomunitateko esperientziak jaso diren; eta beste aldetik, enpresa publiko baten partaidetzan sartutako kooperatiba baten esperientzia. Azken hau, lankidetza publiko-kooperatiboaren ereduaren kasu paradigmatikoa izango delarik.

ESSko enpleguari bideratutako politika publikoei dagokienez, enpresak sortzeko helburua duten neurriak eta ekintzailetza sustatzeko egituren sorkuntza helburu duten neurriak bereizi ditugu gure sailkapenean. Enpresak sortzeko helburua duten neurrien artean, tokiko eragileen partetik inplikazio maila ezberdina duten esperientziak aztertu ditugu. Inplikazio maila txikienarekin, orientazio zerbitzuak eskaini dituen esperientzia bat daukagu. Kasu honetan, garapen agentziatik ESSak berezkoak dituen laguntza zerbitzuetara bideratutako esperientzia izan da Kimu Bat S.L.L. Inplikazio gradu handiagoarekin, dinamizazio eta errazte zerbitzuak eskaini dituzten bi garapen agentzien kasuak jaso dira. Kasu hauetan, Goiener S.Coop eta Lanerain (laneratze enpresa) sortzeko orduan, Goierriko zein Debabarrenako garapen agentziek proiektua dinamizatu, bertan parte-hartu eta giza-, finantza- eta baliabide fisikoak eskura jarri dituzte. Azkenik, kapital sozial publikoa duten laneratze enpresa baten (Oarsotek/Badiaberri) eta enplegu zentro berezi baten (Usoa) esperientziak jaso dira.

Bukatzeko, ESSko ekintzailetza sustatzeko egituren sorkuntzan eragiten duten neurriei dagokienez, kudeaketa komunitarioa duten ekipa- 
mendu publikoen lagapena eta lanbide heziketara lotutako zentroak bereizi daitezke. Ekonopoloa eta Iturola antolaketa publiko-komunitarioa duten udal eta eskualde mailako Co-working espazioak dira non ESSaren inguruan lan egiten duten hainbat eragileek topo egin dezaketen eta esperientziak, proiektuak eta baliabideak partekatu. Bestalde, lanbide heziketa zentroen ekimenez sortutako ekintzailetza ontzeko bi egitura jaso ditugu: Azaro Fundazioa Lea-Artibain eta WorkLan Bilbon.

\subsection{Azterketaren emaitzak}

Atal honetan, ikerketaren emaitza nagusienak aztertuko dira, esperientzien dokumentazio lanetik zein ondoren burututako talde-dinamikatik lortutako ondorio esanguratsuenak bilduz. Horretarako, batez ere, honako alderdiak xerkatu ditugu: esperientzien elementu gakoak, faktore bideratzaile zein mugatzaileak, eta esperientziak beste lurraldeetan ernamuintzeko beharrezkoak diren elementuak.

\subsubsection{ESPERIENTZIEN GARAPENERAKO ELEMENTU GAKOAK}

Esperientzien elementu gakoei dagokienez, hiru dimentsio arakatu izan dira bereziki: esperientziek duten lotura instituzionala, lurralde errotzea eta gizarte-mobilizazioa. Elementu gako hauetako bakoitzak funtsezko galdera bati erantzun nahi diolarik:

-Zein izan da eta da tokiko erakundearen inplikazio-maila aztertutako esperientzian? Lotura instituzionala aztertzeko. Horretarako, tokiko erakundeak prozesuaren bi fasetan izan duen parte-hartze maila dokumentatu da: hasierako abiaraztean eta egungo antolakuntza egituraketan.

-Zein da aztertutako esperientziaren lurralde lotura? Lurralde errotzea aztertzeko. Horretarako, esperientziaren lurraldearekiko duen atxikimendua bi ikuspegitatik aztertu da: ekimenaren eta identifikatutako lurralde beharren arteko korrelazio maila eta lurraldeko gizarte- eta enpresa-eragileek esperientzian duten parte-hartze maila.

—Zer gizarte-mobilizazio eragin du aztertutako esperientziak? Gizartemobilizazioa aztertzeko. Horretarako, gizartearen erakarpen maila bi zentzutan arakatu da: lurraldeko biztanleen atxikitze maila eta esperientziaren bokazio sozial nagusia.

Lotura instituzionalari so eginez, maila ezberdinetako inplikazioa duten esperientziak aztertu ditugu eta ezinezkoa da patroi bakarra definitzea. Es- 
perientzien abiarazte prozesuetan, gutxienez hiru patroi antzeman daitezke: aldebiko izaera duena, non erakunde publikoaren eta ESSaren antolakundearen elkarlanaren ondorengo ekimena sortu den (3., 4., 5., eta 10. esperientziak); eta aldebakarreko izaera duena, bai erakunde publikoaren ekimenez sortu delako (6., 7., 9., 11., 12. eta 13. esperientziak), edo ESSaren ekimenez ernatu delako (1., 2., 8., 14., 15. eta 16. esperientziak).

Era berean, gaur gaurkoz duten konfigurazioari dagokionez, abiarazte prozesuen aniztasunaren ageriko aztarnak aurkitu ditzakegu. Izan ere, era askotako antolaketa ereduei erantzuten diete, non tokiko erakundearen parte-hartze organikoa nabarmen aldatzen den esperientzia batetik bestera. Arestian aipatu dugun moduan, inplikazio gradurik handiena ekimenaren kapital soziala \%100ean publikoa denean ematen da (11. eta 12. esperientziak). Inplikazio maila bat beherago kooperatiba baten parte-hartzea duen enpresa publikoaren kasua legoke (5. esperientzia). Hurrengo mailan, ESSko ekimenean parte-hartzen duten tokiko erakundeak leudeke, bai baliabideak eskaini dituztelako edo baita ere kapital sozialean ekarpen bat egin dutelako (1., 2., 9., 10., 15. eta 16. esperientziak). Jarraian, espazio publikoen lagapena edo zerbitzu publikoen lizitazioak leudeke. Kasu hauetan, ESSaren eta administrazio publikoaren arteko artikulazio organikoa txikiagoa litzateke, bi aldeen arteko harremana kontratu baten bitartez soilik ezartzen bai da (3., 4., 6., 7., 13. eta 14. esperientziak). Eta azkenik, tokiko erakundeek batez ere bitartekotza funtzioa bete duten esperientziak leudeke, non jasotako eskaerak zuzenean ESSko erakunde aholku-emaileetara bideratu dituzten (8. esperientzia).

Lurralde lotuari begira, oro har, esperientzia guztiek tokiko garapenaren ohiko bi helburuei erantzuna ematea bilatzen dute: desenplegua eta tokiko ekonomiaren suspertzea edo dinamizazioa. Eta, aldi berean, hauen barnean bereizi dezakegu desenpleguaren auziari erantzuna emateko, alde batetik, enplegu orokorra sustatzera bideratzen direnak (1., 2., 8.,15. eta 16. esperientziak) eta bestetik kolektibo ahulenen enplegagarritasunera bideratzen direnak (10., 11. eta 12. esperientziak). Bestalde, helburu gisa ekonomiaren suspertzea dutenen artean, eskualdean sektore estrategiko gisa identifikatu dituztenetan arreta jartzen dutenak aurki ditzakegu (9., 10., 11., 13., 14. eta 16. esperientziak) eta bestetik, udal zerbitzu bat ematera bideratzen direnak (3., 5., 6., 7. eta 12. esperientziak). Ikusi daitekeenez, esperientzia batzuk bi helburu orokor hauek bateratuko lituzkete. Azkenik, badaude ere ekonomia solidarioa edo ekonomia sozial eraldatzailea sustatzea helburu duten zenbait esperientzia (1. 3., 4., 9. eta 14. esperientziak).

Lurraldeetako gizarte- eta enpresa-sarearekin artikulatzeko gaitasunari dagokionez ere (lurralde loturaren bigarren elementu bezala identifikatu duguna) errealitate hagitz ezberdinak aurki ditzakegu. Zentzu 
honetan, inplikazio maila gutxien duten kasuak administrazio publikoa soilik mobilizatu dutenak dira (7., 11. eta 12. esperientziak). Mobilizazio maila altuago batean, administrazio publikoaren eta ESSko antolakundeen arteko lankidetzaren ondorioz sortu diren lankidetza-hitzarmenak, partenariatuak, politika publikoen baterako eraikuntza, espazio publikoen kudeaketa komunitarioa, etab. barneratzen dira; maila honetan kokatzen direlarik esperientzia gehienak (3., 4., 5., 6., 8., 9., 13. eta 14. esperientziak). Hurrengo maila batean, aipatutako bi eragile hauetaz gain heziketa zentroak edo unibertsitateak inplikatzen dituztenak identifika genitzake (1., 2. eta 15. esperientziak). Eta azkenik, eragile publikoak, kooperatiboak, enpresarial pribatuak, hezkuntzakoak eta gizarte- edo elkarte-arlokoak inplikatzen dituztenak daude (10. esperientzia, eta, batez ere, 16. esperientzia). Azken hauek, tokiko eragileak ESSaren inguruan artikulatzeko izan duten gaitasunagatik, lurralde-ekosistemak deritzogunak sortzea lortu dutelarik.

Hirugarrenik, lortu duten gizarte-mobilizazioari dagokionez, masa kritiko handiena mobilizatzen duten esperientziak ekonomia solidarioa sustatzea helburu dutenak dira. Izan ere, ekonomia solidarioak hainbat sare ditu, eta sare horiek, era berean, pertsonek proiektu horietan borondatez parte hartzea sustatzen baitute. Horrelakoak dira Goiener edo Koopfabrika kasuak, funtsezkotzat jotzen baitute proiektuari borondatez eusten dioten pertsonen sarea. Era berean, mobilizazio maila handia erakusten dute ere lurralde artikulazio handiena erakusten duten esperientziek, hots, lurraldeekosistemak deiturikoak. Izan ere, hauek, borondatezko lan-formulen bidez sostengatuta egon gabe, gai dira esperientzia berean lurraldeko eragile publiko, pribatu, ekonomiko edo sozial ugari barneratzeko (10. eta 16. esperientziak). Maila ertainean, tokiko administrazioaren eta ESSaren arteko lankidetzaz gain, hirugarren eragile bat sartzeko gai diren esperientziak kategorizatzen ditugu, dela esparru pribatu enpresarialeko eragilea (11. esperientzia), dela elkarte-arlokoa (4. esperientzia). Eta azkenik, esperientzia modu iraunkorragoan bultzatzen duen masa kritiko hori gabeko esperientziak daude, hala nola, profil ekintzailerik ez dagoelako (1. esperientzia), errelebo-arazoengatik (13. esperientzia), kontratua bera gainditzen duen harremanik ez dagoelako, etab.

Bestalde, esperientzien bokazio sozialari dagokionez, oro har enplegua sortzea helburu duten esperientziak daude, ESSaren formulen bidezko enplegua sortzea helburu duten esperientziak daude (bai biztanleria orokorraren enpleguari begira, eta baita ere, kolektibo ahulenen enplegua sortzeari begira). Amaitzeko, ekonomia solidarioa sustatzeko helburua duten esperientziak daude non energia berriztagarriak, mugikortasun iraunkorra, mikro-kredituak (finantza etikoak), ekonomia solidarioko ekintzailetza edo/ eta enpresa sareak sortzeko helburu sozial ezberdinak aurkitu daitezkeen. 
Hurrengo taulan aztertutako elementu gakoen laburpena agertzen da:

\section{5. taula}

Ikerturiko esperientzien elementu gako nagusiak

\begin{tabular}{c|l|l}
\hline $\begin{array}{c}\text { Elementu } \\
\text { gakoa }\end{array}$ & \multicolumn{1}{|c|}{ Aztertutako aldagaiak } & \multicolumn{1}{c}{ Emaitza orokorrak } \\
\hline \multirow{4}{*}{$\begin{array}{c}\text { Lotura } \\
\text { instituzionala }\end{array}$} & $\begin{array}{l}\text { Tokiko erakundearen par- } \\
\text { te-hartzea abiaraztean }\end{array}$ & $\begin{array}{l}\text { Aldebikoa edo aldebakarrekoa (bai ESSa- } \\
\text { ren ekimenez aurrera eraman delako edo } \\
\text { tokiko erakundearen ekimenez). }\end{array}$ \\
\cline { 2 - 4 } & $\begin{array}{l}\text { Tokiko erakundearen par- } \\
\text { te-hartzea gaur egungo an- } \\
\text { tolakuntza konfigurazioan }\end{array}$ & $\begin{array}{l}\text { Inplikazio maila ezberdinak: kapital so- } \\
\text { zialaren \% 100a izatetik, laguntza edo/ } \\
\text { eta bitartekotza zerbitzuetara. }\end{array}$ \\
\hline \multirow{4}{*}{$\begin{array}{c}\text { Lurralde } \\
\text { lotura }\end{array}$} & $\begin{array}{l}\text { Esperientziaren eta lurral- } \\
\text { de-beharren arteko korre- } \\
\text { lazioa }\end{array}$ & $\begin{array}{l}\text { Desenplegua (bai orokorra, bai kolek- } \\
\text { tibo ahulenena), tokiko ekonomiaren } \\
\text { suspertzea (sektore estrategikoetan edo } \\
\text { zerbitzu publikoen bitartez) eta ekono- } \\
\text { mia solidarioa sustatzea. }\end{array}$ \\
\cline { 2 - 4 } & $\begin{array}{l}\text { Lurraldeko beste eragileen } \\
\text { parte-hartze maila }\end{array}$ & $\begin{array}{l}\text { Parte-hartze maila ezberdinak: soilik ad- } \\
\text { ministrazio publikoa mobilizatu dutene- } \\
\text { tatik ESSko lurralde-ekosistemak sortzea } \\
\text { lortu dituztenetara. }\end{array}$ \\
\hline \multirow{2}{*}{$\begin{array}{l}\text { Gizarte- } \\
\text { mobilizazioa }\end{array}$} & $\begin{array}{l}\text { Lurraldeko biztanleen } \\
\text { atxikitzea }\end{array}$ & $\begin{array}{l}\text { Ekonomia solidarioarekin eta lurralde } \\
\text {-ekosistemekin lotura handiagoa duten } \\
\text { ekimenak izan dira atxikipen handiagoa } \\
\text { jaso dutenak. }\end{array}$ \\
\cline { 2 - 4 } & $\begin{array}{l}\text { Enplegua sortzea, ESSko enplegua (oro- } \\
\text { korra edo kolektibo ahulenena) sortzea } \\
\text { eta ekonomia solidarioa sustatzea (ener- } \\
\text { gia berriztagarriak, mugikortasun iraun- } \\
\text { korra, finantza etikoak etab.). }\end{array}$ \\
\hline
\end{tabular}

Iturria. Egileek egina.

\subsubsection{FaKTore Bideratzaile ETA MUgatZaileak}

Esperientziak aurrera eramatea ahalbidetu duten faktore bideratzaileei eta hauen garapena zaildu edo moteldu duten faktore mugatzaileei dagokienez, hurrengo emaitza nagusiak bildu dira. 
Gehien errepikatu diren faktore bideratzaileei dagokienez, alderdi profesionalak nabarmentzen dira. Hala nola, esperientzien profesionalizazioarekin eta kudeaketa ereduekin zerikusia dutenak, lurraldea eta haren ekonomia- eta gizarte-egituren ezagutza mailarekin lotura dutenak, baita lan-malgutasunarekin edo lanbide- edo prestakuntza-profil desberdinetara egokitzeko gaitasunarekin lotura dutenak ere. Bestalde, lurraldearen alderdi politiko-instituzionalak ere faktore bideratzaileak bezala identifikatu izan dira. Izan ere, esperientzia askok nabarmendu egiten dute borondate politikoaren, segurtasun juridikoaren edo tokiko garapen agentziekiko eta bestelako administrazio publikoarekiko lankidetzaren garrantzia, politika eta zerbitzu publikoak ko-eraiki eta kudeatzeko orduan. Era berean, ESSko antolakundeen sareak eta hauen arteko interkooperazioa, ESSko eskaintza zabala izatea etab. bezalako alderdiak ere azpimarratzen dituzte lurralde edo sektore berdineko ESSko beste erakundeekin kooperatzeko eta lurraldeko beste eragile sozioekonomiko batzuekin eta elkartegintzarekin batera lan egiteko.

Faktore mugatzaileei dagokienez ere, alderdi ekonomiko eta profesionalak besteren gainetik nagusitzen dira. Hauek, finantzaketa lortzeko arazoekin, jarduera sektorearen berezitasunekin edo lanbide-profil egokiak eta ekintzaile berriak ez erakartzearekin lotzen dituztelarik. Bestalde, zailtasun gisa ere adierazi zen esperientzien helburua bera.Izan ere, esperientzia hauek konbinatu egiten dituzte enplegua sortzea (kasu batzuetan gainera, kolektibo zaurgarrietan arreta jarriz) eta tokiko ekonomiak sozialki eta/edo ingurumenaren aldetik arduratsuagoa den ikuspegitik batetik dinamizatzeko jarduera ekonomiko berriak sortzea. Azkenik, zailtasun handiena bezala kontsideratu ez zen arren, komunikazio alderdien zailtasunari dagokionez adostasun handia dagoela nabarmendu behar da. Bereziki, ekintzaileek eta administrazio publikoek (teknikariak eta politikariak) ESSarekiko eta ESSa sustatzeko formulekin duten ezagutza maila eskasarekin zerikusia dutenak. Gai honek talde dinamikaren eztabaidaren zati handi bat hartu zuen eta epe labur edo ertainean lan ildo egingarri gisa identifikatu zen.

Ikusi dezakegunez, oro har, alderdi profesional eta ekonomikoak garrantzitsuak dira alderdi bideratzaileei zein zailtasunei erreparatzen diegunean. Ondorioztatu dezakegu beraz, hauek gauzatzea lortzen direnean ezinbesteko faktoreak bihurtzen direla esperientziaren garapenerako, baina gauzatu ezean, muga garrantzitsuak sortzen dituztela.

\subsubsection{ESPERIENTZIAK BESTE ESKUALDE BATEAN ERREPLIKATZEKO FAKTOREAK}

Azterketaren emaitzekin bukatzeko, aztertutako esperientziak beste lurralde edo eskualde batean aplikagarriak izateko elementuetan arreta jarri 
zen. Kasu honetan, esperientziak oso ezberdinak direnez euren artean, eztabaida termino orokorragoetan jorratu zen, hiru gai nagusi nabarmendu zirelarik: ESSaren ezagutza, lankidetza publiko-pribatua eta Garapen-en (Garapen Agentzien Euskal Elkartea) eginkizuna.

Esperientziak beste lurraldeetan hozitu ahal izateko identifikatutako lehenengo faktorea, ESSaren inguruko ezagutza mailaren zabalpena izan da. Izan ere, ezinbestekotzat jotzen da gizartean modu orokorrean eta administrazio publikoan espezifikoki ESSaren inguruko ezagutza maila handitzea. Ildo honetan, arestian esan bezala, nahiko iritzi orokorra dago ESSaren inguruko ezagutza maila eskasa dela administrazio publikoko teknikarien artean, maila guztietan. Maila politikoari dagokionez, diskurtsoetan geroz eta ESSari lotutako gai gehiago daudela uste bada ere, oraindik ere borondate politiko handiagoa beharrezkoa dela uste da, diskurtsoetatik ESSa bultzatzeko konpromisora pasatzeko. Hots, esandakotik egindakora oraindik badagoela tartea. Horretarako, ESSak bere osotasunean eskaintzen dituen lurraldeentzako onurak erakutsi beharko liratekeela argudiatzen da.

Orokorrean, ezinbestekotzat jotzen da bi kolektiboak (politikoa eta teknikoa) prestatzea dituzten eskumenetan, klausula sozialetan, ESSaren egituratze moduetan eta abarretan. Are gehiago, zenbait ikuspuntutatik, teknikarien gain egin beharreko ezagutzaren zabalkuntza lana lehenesten da, talde egonkorragoa osatzen dutelako politikariek baino. Gainera, egungo testuinguru sozioekonomikoa kontuan hartuta, errazagoa kontsideratzen da ESSak eskaintzen dituen onurengatik politikariak konbentzitzea teknikariak baino, arlo horietan ezjakintasunak sor ditzakeen zailtasunengatik (batez ere aipatutako eskumenen, klausula sozialen, ESSaren egituratze moduen arloan).

Ezagutzaren zabaltze lan guzti honerako, batetik, garapen agentzien papera aldarrikatzen da administrazioko langileak ESSra hurbiltzeko, eta bestetik, unibertsitatearen eta lanbide-heziketako ikastetxeen zeregina ere nabarmentzen da. Izan ere, azken hauek, funtsezkotzat jotzen dira gizarteak ESSari buruz duen ezagutza handitzeko eta etorkizuneko ekintzaileak ESSaren formetara lerratzeko.

ESSan oinarritutako esperientziak errepikatzeko bigarren faktore nagusia, lankidetza publiko-pribatuaren inguruan antzeman zen. Batez ere, garapen agentziek administrazio publikoaren eta ESSaren arteko elkarlana sustatzeko duten eginkizunari buruz. Alde batetik, ESSa garapen agentzien lan ildoetan sartu behar dela argudiatzen da. Izan ere, ESSak duen helburu ekonomiko eta sozial bikoitz hori bateratzea konplexua da eta kasu batzuetan laguntza publiko handiagoa eskatzen du, zailagoa baita enplegu eta jarduera lehiakorrak sortzen jarraitzea. Horregatik, merkatua ESSra bideratzeko beharra azpimarratzen da. Bereziki, administrazio publikoak egin 
dezakeen horri lotuta: ESSarekin kontratu publikoak aurrera eramatea, kontratazio publikoan klausula sozialak aplikatzea, etab. Zentzu horretan, garapen agentziek ESSa sustatzeko egin dezaketena da zerbitzu publikoen ekoizpenarekin lotutako merkatu-aukera berriak aztertzea.

Bukatzeko, Garapen-en eginkizunari buruzko eztabaida interesgarria eman zen. Izan ere, ESSa sustatzeko estrategia koordinatua egin beharko luke Garapen-ek eskualde guztietan? Kasu honetan, bi iritzi desberdin baina bateragarriak jaso dira. Alde batetik, oro har, garapen agentzien ordezkariek lurralde bakoitzaren berezitasunak errespetatzeko beharra azpimarratzen zuten. Eskualde bakoitza desberdina da, bere behar propioak eta dinamika instituzional partikularrak baititu. Beraz, hauek, behetik abiatutako eredu baten alde egin zuten. Bestalde, ESSaren ordezkariek batez ere, ESSa Garapen-en estrategiaren barruan barneratzea beharrezkoa dela argudiatzen zuten. Hala ere, esan bezala, bi jarrera horiek bateragarriak izan (beharko) litezke. Izan ere, Garapen-ek ESSa sustatzeko estrategiaren barruan lurraldeen behar komunak aseko dituzten hainbat ekimen burutu ditzake. Hala nola ESSaren inguruko prestakuntza-eskaintza, ESSa sustatzeko materialak eta tresnak zabaltzea, etab. Baina aldi berean, proiektu espezifikoak behetik sortzen utzi; lurralde bakoitzean ezarritako garapen agentziek dinamizatuta.

\section{Ondorioak}

Artikulu honetan aurkeztutako ikerketa honetatik eratorri daitekeen lehenengo ondorioa zera da: tokiko erakundeek (udalak, garapen agentziak...) ESSa sustatzeko duten politika publikoen kopuru eta aniztasuna handia da. Eta, aldi berean, ESSak tokiko beharrak asetzeko eta esku-hartze publikoaren helburuei erantzun egokia emateko orduan egituraketa forma ezberdinak hartzeko gaitasuna duela.

Izan ere, alde batetik, ESSa sustatzeko politika publikoen marko orokorrak zehazten duenez, eta gure ikerketa enpirikoak erakusten digunez, ESSaren sustapenerako politika publiko ezberdinak aplikatu daitezke lurraldearen eta beharraren arabera. Horrela, adibidez, kalitatezko enplegua sortu, kolektibo ahulen laneratzea lortu, sektore estrategikoen burujabetza berreskuratu edo zerbitzu publikoen kooperatibizazioa bezalako helburuak erdietsi daitezkeela ikusi dugu.

Eta bestalde, ESSak behar bakoitzari egokitutako formula egokienak aurkitzea ahalbidetzen du. Hala nola, lan-kooperatibak edo -sozietateak, laneratze enpresak, enplegu zentro bereziak, erabiltzaileen elkarteak edo kooperatibak, partaidetza publikoko kooperatibak, espazioen kudeaketa publiko -kooperatibo edo -komunitarioko formulak eta abarren bitartez. 
Ikerketatik eratorri dezakegun bigarren ondorio bat da, ESSak zerbitzua eskaintzen duenean politika publikoaren helburuaren eta emandako zerbitzu horren arteko bat egite handiagoa dela.

Izan ere, helburu orokorrei begira bat egite gradu handia erakusten dute biek zerbitzua eta bazkideen zein komunitatearen beharrak asetzea lehenesten baitute errentagarritasun ekonomikoaren aurretik. Helburu espezifikoei begira, ESSak garapenerako tokiko erakundeen ohiko helburu bikoitzari erantzuna emateko gaitasuna erakusten duela ikusi dugu: ESSak enplegua sortzen du eta tokiko ekonomia suspertu eta dinamizatu dezake.

Are gehiago, ESSak enpresa kapitalistek sortzen ez duten bestelako onurak sortu ditzake lurraldeetan. Hala nola kalitatezko lana eta lanaren defentsa, gizarte bazterketa egoeran dauden pertsonen laneratzea eta gizarteratzea, aberastasunaren banaketa bidezkoagoa, ekonomiaren iraunkortasuna ingurumen eta termino sozialetan, ekonomiaren demokratizazioa, sektore estrategikoen gaineko burujabetzak berreskuratzea, etab.

Dena dela, badaude ESSaren markoan dauden esperientziak sustatzea errazten edo zailtzen duten faktore bideratzaile edo mugatzaileak ere. Artikulu honetan, aztertutako esperientzietan eragin dutenak jaso dira, eta batez ere, faktore profesionalei, ekonomikoei eta ESSko antolakundeen artean eta administrazio publikoarekiko duten lankidetza harremanei dagokienak azpimarratu dira. Era berean, etorkizunean horrelako esperientziak beste eskualdeetan erreplikatzeko beharrezkoak izan daitezkeen faktoreei begira, tokiko erakundeetako (eta goragoko mailetako) teknikarien formakuntza, lankidetza publiko-kooperatibo-komunitarioa eta Garapen-en partetik eskualde bakoitzari bere beharren arabera ESSa sustatzea ahalbidetzen dion estrategia koordinatu bat aplikatzea beharrezkoa dela antzematen da.

\section{Bibliografia}

BAKAIKOA, B. eta MORANDEIRA, J. (2012). «El cooperativismo vasco y las políticas públicas», Ekonomiaz-Revista Vasca de Economía, 79: 234-263.

CATALÀ, B. (2020): Las políticas públicas de economía social desplegadas por los ayuntamientos de la Comunitat Valenciana, Edl CIRIEC-Espańa e IUDESCOOP, Valencia.

CHAVES, R. (2009): «Las políticas públicas de fomento de la Economía Social en España y en Europa. En Informe para la elaboración de una ley de fomento de la Economía Social en España. CIRIEC-España, Valencia.

CHAVES, R. (2010): «Las actividades de cobertura institucional: infraestructuras de apoyo y políticas públicas de fomento de la economía social», en: Monzón, J.L. (dir.) (2010): La Economía social en España en el año 2008, Ed. CIRIECEspaña, Valencia, 565-592. 
CHAVES, R. (2012): Las políticas públicas y las cooperativas, Revista Ekonomiaz, 79(01), 169-200.

CHAVES, R. (2019): «La segunda generación de políticas de fomento de la economíasocial en España y en la Comunitat Valenciana. Un primer balance», in Fajardo, y Chaves, (dir): La economía social en la Comunitat Valenciana: regulación y políticas públicas, CIRIEC-España, Valencia.

CHAVES, R., VIA, J. \& GARCIA, J. (2019): La política pública de fomento de la economía social y solidaria en Barcelona. UNRISD.

CHAVES, R. \& SAVALL, T. (2020): «La política de promoción de la economía social (cooperativas y sociedades laborales) en la Comunitat Valenciana». En CHAVES, R. (dir), La nueva generación de políticas de fomento de la economía social, Tirant lo Blanc editorial, Valencia.

CHAVES, R. \& MONZÓN, J. (2019): Buenas prácticas en las políticas públicas relativas a la economía social europea tras la crisis económica.Comité Económico y Social Europeo, Bruselas.

CHAVES-ÁVILA, R. \& GALLEGO-BONO, J.R. (2020): «Transformative Policies for the Social and Solidarity Economy: The New Generation of Public Policies Fostering the Social Economy in Order to Achieve Sustainable Development Goals. The European and Spanish Cases». Sustainability, 12(10), 4059.

ESTELA, E. (2014): «Hacia una política local innovadora en apoyo de la economía social y solidaria» in García Jané, J. (coord): Guía de economía social y solidaria para la administración local, Diputación de Barcelona, Barcelona.

FAJARDO, G. (2019): «La regulación y fomento de la Economía Social en la ComunidadValenciana a debate.» in Fajardo, y Chaves, (dir): La economía social en la Comunitat Valenciana: regulación y políticas públicas, CIRIEC-España, Valencia.

FAJARDO, G. \& CHAVES, R. (2019): La economía social en la Comunitat Valenciana: regulación y políticas públicas, CIRIEC-España, Valencia

GARCÍA JANÉ, J. (coord.) (2014): Guía de economía social y solidaria para la administración local, Diputación de Barcelona, Barcelona.

GARCIA JANÉ, J. [coord.] (2016), 21 propostes per fomentar l'economia social i solidària des del ajuntaments, DIBA

GARCÍA JANÉ, J. (2019): «Balanç y reptes de les primeres polítiques oúbliques d'ESS», Nexe Quaderns d'autogestió y economia cooperativa, n. ${ }^{\circ} 44$, 24-34.

GURIDI, L.\& PÉREZ DE MENDIGUREN, J.C. (2014): La dimensión económica del desarrollo humano local: la economía social solidaria, Euskal Herriko Unibertsitatea (UPV/EHU), Hegoa Institutua.

JUSTE, J. J., GÓMEZ, J. M. eta FERNÁNDEZ, J. (2011): «Economía social y desarrollo local rural. Un análisis de sus sinergias», Estudios de Economía Aplicada, 29(1), 189-221.

MORANDEIRA, J. (2013): «El servicio público de fomento de la Economía Social en el País Vasco desde una perspectiva de orientación al mercado. Propuestas y acciones», Tesis-Doctoral, Universidad del País Vasco/Euskal Herriko Unibertsitatea, Donostia-San Sebastián. 
MORANDEIRA, J., ETXEZARRETA, E. \& ETXEBARRIA, A. (2020): «Políticas de promoción de la economía social vasca». En CHAVES, R. (dir), Estudio sobre Análisis comparado de las políticas públicas de fomento de la economía social en la Comunitat Valenciana, Comunidades Autónomas y Estado Español, CIRIEC-España, Valencia, 171-195.

MOZAS, A. eta BERNAL, E. (2006): «Desarrollo territorial y economíasocial», CIRIEC-España, revista de economía pública, social y cooperativa, (55), 125140.

PIKE, A., TOMANEY, J., eta RODRIGUEZ A. (2006): Local and regional development, Routledge.

SUBIRATS, J. (2014): «Notas sobre cambio de época y economía social. ¿Nuevas políticas de desarrollo local?» in García Jané, J. (coord): Guía de economía social y solidaria para la administración local, Diputación de Barcelona, Barcelona. 